\title{
STRUKTUR MODAL PERUSAHAAN PROPERTY DAN REAL ESTATE
}

\author{
Ellyana $^{1}$, Herman Ruslim² \\ ${ }^{1}$ Program Studi Manajemen, Fakultas Ekonomi dan Bisnis, Universitas Tarumanagara \\ Email: aellyana37@gmail.com \\ ${ }^{2}$ Program Studi Manajemen, Fakultas Ekonomi dan Bisnis, Universitas Tarumanagara* \\ Email: herman.ruslim@gmail.com
}

*Penulis Korespondensi

Masuk : 04-02-2021, revisi: 10-02-2021, diterima untuk diterbitkan :02-03-2021

\begin{abstract}
ABSTRAK
Tujuan dilakukan nya penelitian ini adalah untuk menganalisis pengaruh dari profitabilitas, likuiditas, collateral dan investment opportunity terhadap struktur modal baik secara parisal maupun secara simultan. Penelitian ini dilakukan pada perusahaan yang bergerak di sektor property dan real estate yang terdaftar di BEI (Bursa Efek Indonesia) periode 2016-2019 dengan pemilihan sampel menggunakan teknik purposive sampling. Metode yang digunakan dalam penelitian ini adalah analisis regresi data panel (Panel Least Square) yang diuji dengan menggunakan software Eviews 11 Student Version. Adapun hasil dari penelitian ini adalah profitabilitas berpengaruh secara negative dan signifikan dan investment opportunity berpengaruh secara positif dan signifikan terhadap stuktur modal, sedangkan likuiditas dan collateral tidak mempunyai pengaruh yang signifikan terhadap struktur modal. Secara simultan semua variabel yang diteliti mepunyai pengaruh yang signifikan terhadap struktur modal.
\end{abstract}

Kata Kunci: Struktur Modal, Profitabilitas, Likuditas, Collateral, Investment Opportunity

\begin{abstract}
Abstract: The purpose of this research is to analyze the effect of profitability, liquidity, collateral and investment opportunity on the capital structure both parisally and simultaneously. This research was conducted on companies engaged in the property and real estate sectors listed on the IDX (Indonesia Stock Exchange) for the period 20162019 by selecting samples using purposive sampling technique. The method used in this research is panel data regression analysis (Panel Least Square) which was tested using Eviews 11 Student Version software. The results of this study are that profitability has a negative and significant effect and investment opportunity has a positive and significant effect on capital structure, while liquidity and collateral do not have a significant effect on capital structure. Simultaneously all the variables studied have a significant influence on the capital structure.
\end{abstract}

Keywords: Capital Structure, Profitability, Liqudity, Collateral, Investment Opportunity

\section{PENDAHULUAN}

\section{Latar Belakang}

Struktur modal (Capital Structure) merupakan perbandingan antara pendanaan dari hutang dan ekuitas atau modal sendiri yang digunakan perusahaan, untuk menetapkan struktur modal, suatu perusahaan harus mempertimbangkan faktor-faktor yang dapat mempengaruhi struktur modal itu sendiri antara lain seperti ukuran perusahaan, profitabilitas, likuiditas, struktur aktiva, risiko bisnis dan faktor lainnya. Dalam menentukan struktur modal terdapat dua teori pendekatan yang terkenal yaitu teori pertukaran (Trade off Theory) dan Pecking Order Theory.

Dalam Trade-off theory dikatakan bahwa perusahaan mempunyai target struktur modal, jika perusahaan menambah hutang melampaui batas target struktur modal maka perusahaan akan trade off dengan kebangkrutan. Faktanya seperti yang ditunjukkan pada contoh perusahaan di Gambar 1, penurunan hutang perusahaan PT. Metropolitan Kentjana juga mempengaruhi 
profitabilitas perusahaan yang dimana seharusnya ketika perusahaan menurunkan tingkat hutang maka tingkat profitabilitas perusahaan akan naik, faktanya yang terjadi adalah profitabilitas perusahaan PT. Metropolitan Ketjana malah turun seiring dengan penurunan tingkat hutang. Hal ini tidak sejalan dengan pernyataan Trade-Off Theory.

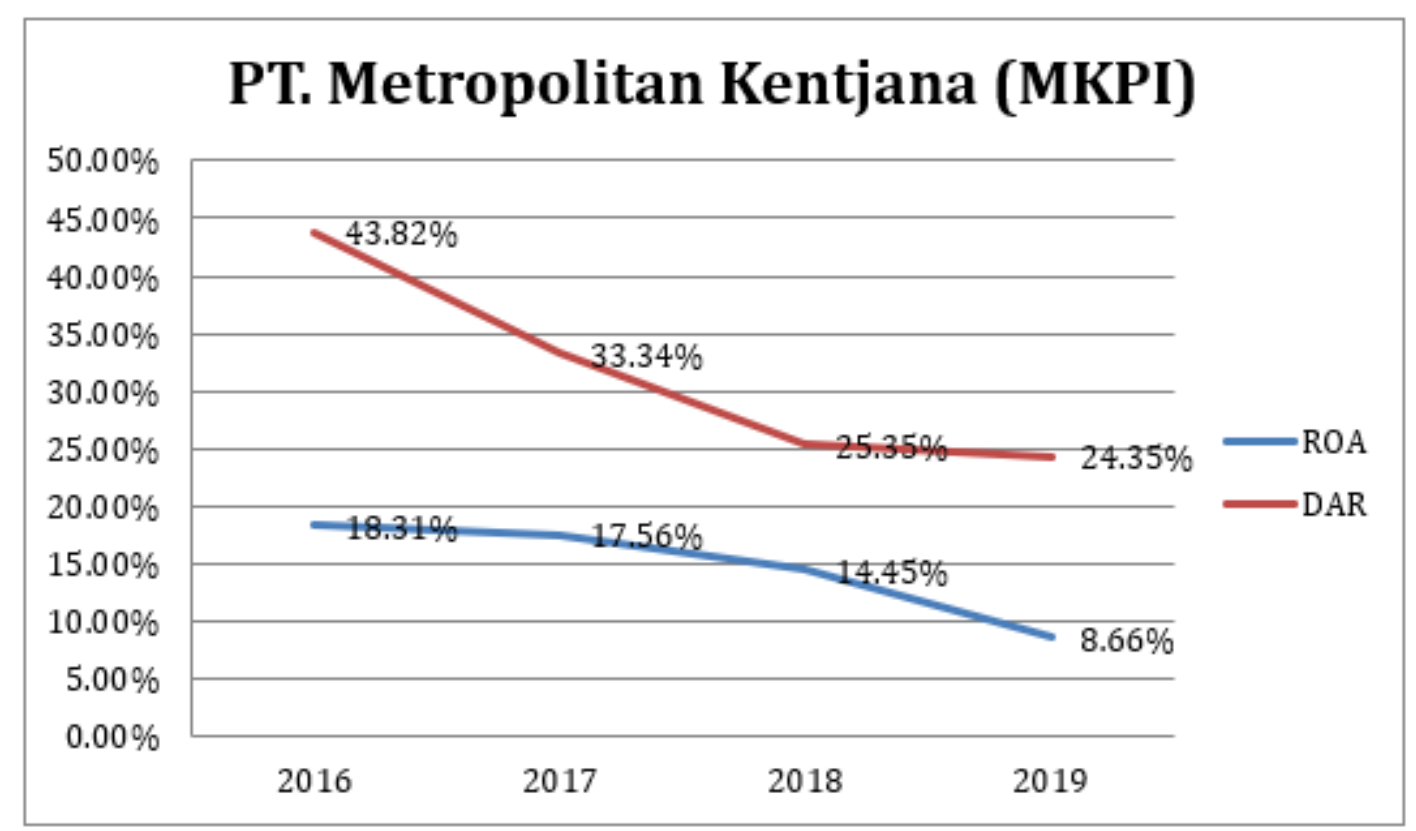

Gambar 1. Grafik Perbandingan ROA dan DAR

Selain itu juga berbagai penelitian tentang faktor-faktor yang mempengaruhi struktur modal pada perusahaan dari berbagai sektor usaha telah banyak dilakukan, hasil dari penelitian-penelitian tersebut menunjukkan hasil yang berbeda-beda (research gap) seperti salah satunya adalah penelitian yang dilakukan oleh. Alipour et al. (2015) Hasil penelitian menunjukkan bahwa variabel seperti ukuran perusahaan, fleksibilitas keuangan, struktur aset, profitabilitas, likuiditas, pertumbuhan, risiko dan kepemilikan negara mempengaruhi semua ukuran struktur modal perusahaan Iran. Hutang jangka pendek dianggap mewakili sumber pembiayaan penting bagi perusahaan di Iran.

Penelitian dilakukan oleh Chandra et al., (2019) menunjukan bahwa hanya variabel profitabilitas yang mempengaruhi return saham. Variabel struktur modal, ukuran perusahaan, growth opportunity, tangibility dan likuiditas tidak berpengaruh signifikan. Variabel yang mempengaruhi struktur modal hanya dipengaruhi oleh growth opportunity, sedangkan variabel lain yang tidak signifikan dan variabel yang mempengaruhi profitabilitas adalah ukuran perusahaan, growth opportunity, keunikan dan volatilitas. Penelitian lainnya dilakukan oleh SaifAlyousfi et al., (2020) menunjukan bahwa profitabilitas, peluang pertumbuhan (growth opportunity), pelindung pajak (tax shield), likuiditas, dan volatilitas arus kas (cash flow) memiliki dampak negatif dan signifikan terhadap ukuran utang (debt measures). Namun, pengaruh agunan (collateral), pajak bukan utang (non -debt tax), dan volatilitas laba terhadap ukuran utang (debt measures) adalah positif dan signifikan. Selain itu, ukuran perusahaan, usia perusahaan, tingkat inflasi dan tingkat bunga merupakan faktor penentu leverage yang penting. 


\section{Kajian teori}

Ada banyak teori yang dikembangkan untuk menentukan struktur modal suatu perusahaan, antara lain adalah trade-off theory dan pecking order theory (Fama dan French, 2002; Frank dan Goyal, 2003; Goyenko et al., 2009; Kayhan dan Titman, 2007), agency costs (Jensen, 1986), market timing (Baker dan Wurgler, 2002; De Bie dan De Haan, 2007; Hovakimian, 2006; Jenter, 2005) dan stock returns (Welch, 2004). Informational asymmetries oleh Myers (1984), lalu perkembangan terakhir dari teori struktur modal adalah Capital Structure theory and empirical evidence. Dari beberapa teori yang disebutkan diatas ada dua teori yang saling bertentangan mengenai pilihan pembiayaan eksternal yaitu Trade-off Theory dan Pecking Order Theory.

\section{Trade-off Theory}

Menurut Modigliani dan Miller (1963) menyampaikan bahwa perusahaan tidak dapat mempunyai hutang yang terlalu besar karena bunga yang akan dibayarkan oleh perusahaan akan besar juga, dan hal itu dapat memperbesar kemungkinan perusahaan akan mengalami kebangkrutan. Jika perusahaan mempunyai hutang yang terlalu besar atau terlalu kecil hal itu akan mempengaruhi nilai perusahaan. Keutungan dari menggunakan hutang sebagai sumber pendanaan adalah pajak yang dibayar perusahaan menjadi kecil karena pembayaran bunga tersebut sehingga menimbulkan penghematan pajak (tax saving), tetapi resikonya adalah perusahaan dapat mengalami kesulitan keuangan dan adanya biaya kebangkrutan (Kraus dan Litzenberger, 1973). Dengan pertimbangan yang ada, trade off theory diperbaharui menjadi dynamic trade off theory. Dalam dynamic trade off theory dijelaskan bahwa perusahaan yang mencapai titik batas optimal adalah perusahaan yang bisa menutupi biaya hutang dari manfaat yang diperoleh dari berhutang (Baker dan Powell, 2005).

\section{Pecking Order Theory}

Myres dan Majluf (1984) mengatakan bahwa perusahaan lebih suka menggunakan pendanaan yang berasal dari internal perusahaan dibandingkan pendanaan yang berasal dari luar perusahaan (eksternal). Dengan pengunaan pendanaan internal ini akan mengurangi biaya agency (agency costs), yang dimana pengurangan biaya agency (angency costs) ini dapat meningkatkan profitabilitas dan nilai perusahaan.

Struktur Modal menurut Menurut Brounen et al. (2006), "Capital structure is one of the main issues in corporate finance. It is an optimal combination of long-term debt and equity and is also an important corporate policy, dealing with a firm's activities, with debts and equity."

Profitabilitas menurut Chen (2004) merupakan ukuran kemampuan perusahaan dalam menghasilkan keuntungan dan mengukur tingkat efisiensi operasional dan efisiensi dalam menggunakan harta yang dimilikinya.

Likuiditas menurut Basri Shoib dan Kamaralzaman (2019) merupakan kemampuan perusahaan dalam mengubah aset jangka pendek menjadi kas tanpa mempengaruhi nilai aset.

Jaminan/kolateral (Collateral) merujuk pada besarnya aset berwujud suatu perusahaan yang digunakan sebagai jaminan ketika perusahaan membutuhkan pendanaan eksternal.

Peluang investasi (Investment Opportunity) merujuk pada bagaimana suatu perusahaan memanfaatkan aset yang dimiliki nya untuk diinvestasikan sehingga dapat meningkatkan pertumbuhan perusahaan (growth). 


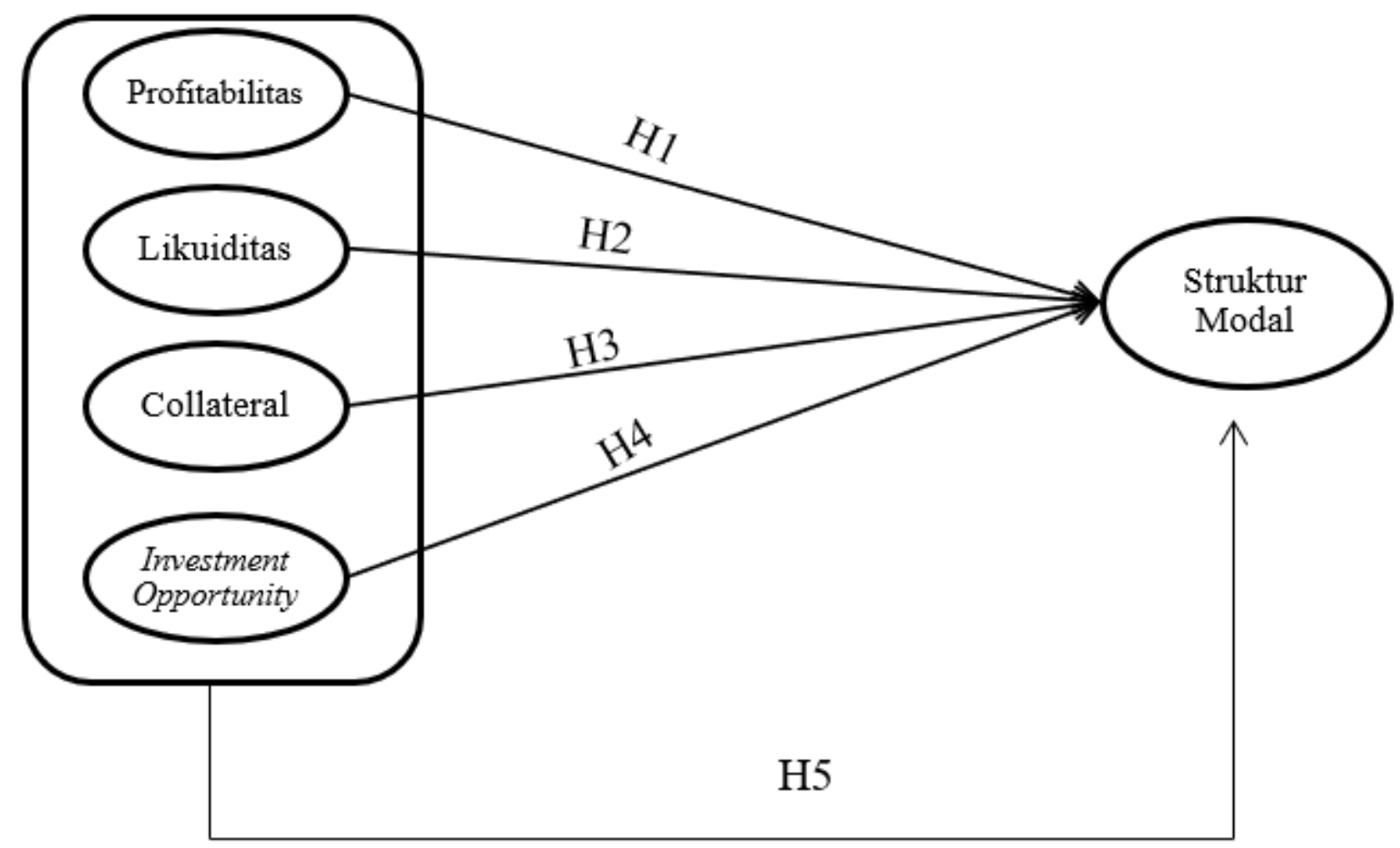

Gambar 2. Model penelitian

Sumber: Saif-Alyousfi et al., (2020), Kyissima et al., (2019), Alipour et al., (2015), Wijaya \& Jessica (2017), Khémiri \& Noubbigh (2018), Basri et al., (2019), Ramili \& Papilaya (2015), Nurcahyani \& Suardikha (2017).

Hipotesis dalam penelitian ini adalah sebagai berikut:

H1: Profitabilitas memiliki pengaruh negative dan signifikan terhadap struktur modal

H2: Likuiditas memiliki pengaruh negative dan signifikan terhadap struktur modal.

H3: Collateral memiliki pengaruh positif dan signifikan terhadap struktur modal.

H4: Investment opportunity memiliki pengaruh positif dan signifikan terhadap struktur modal.

H5: Profitabilitas, Likuiditas, Collateral dan Investment Opportunity secara bersama-sama memilki pengaruh yang signifikan terhadap struktur modal.

\section{METODE PENELITIAN}

Subjek dalam penelitian ini adalah perusahaan yang bergerak dalam sektor bisnis property dan real estate yang sudah terdaftar di BEI (Bursa Efek Indonesia) pada periode 2016-2019. Objek dalam penelitian ini adalah variabel-variabel yang diteliti yaitu Profitabilitas, Likuiditas, Collateral, Investment opportunity sebagai variabel independen dan Struktur Modal sebagai variabel dependen. Profitabilitas yang diukur menggunakan ROA (Return on Assets), Likuiditas yang diukur menggunakan CR (Current Ratio), Collateral yang diukur dengan menggunakan rasio property, plants, and equipment dibagi dengan total assets, Investment Opportunity yang diukur dengan menggunakan market-to-book ratio dan Struktur Modal diukur dengan menggunakan long term debt ratio. Desain penelitian yang digunakan dalam penelitian ini adalah deskriptif, karena penelitian ini dilakukan dengan tujuan untuk mengetahui gambaran pengaruh variabel independen terhadap variabel dependen dalam suatu penelitian.

Penelitian ini menggunakan metode kuantitatif karena lebih berfokus pada hitungan, sehingga data yang digunakan dalam penelitian ini adalah data sekunder. Dimana data sekundernya berupa 
laporan keuangan keuangan yang diperoleh dari situs resmi Bursa Efek Indonesia (BEI) periode 2016-2019. Populasi dalam penelitian ini adalah berjumlah 50 perusahaan, dari populasi tersebut dilakukan pemilihan sampel menggunakan teknik purposive sampling dan diperoleh 30 perusahaan sebagai sampel penelitian ini. Metode yang digunakan dalam penelitian ini adalah analisis regresi data panel (Panel Least Square) yang diuji dengan menggunakan software Eviews 11 Student Version.

\section{HASIL DAN PEMBAHASAN}

\section{Uji asumsi klasik}

Uji asumsi klasik dalam penelitian ini menggunakan uji normalitas dan uji multikolinearitas. Uji normalitas yang digunakan dalam penelitian ini adalah uji Jarque-Bera.

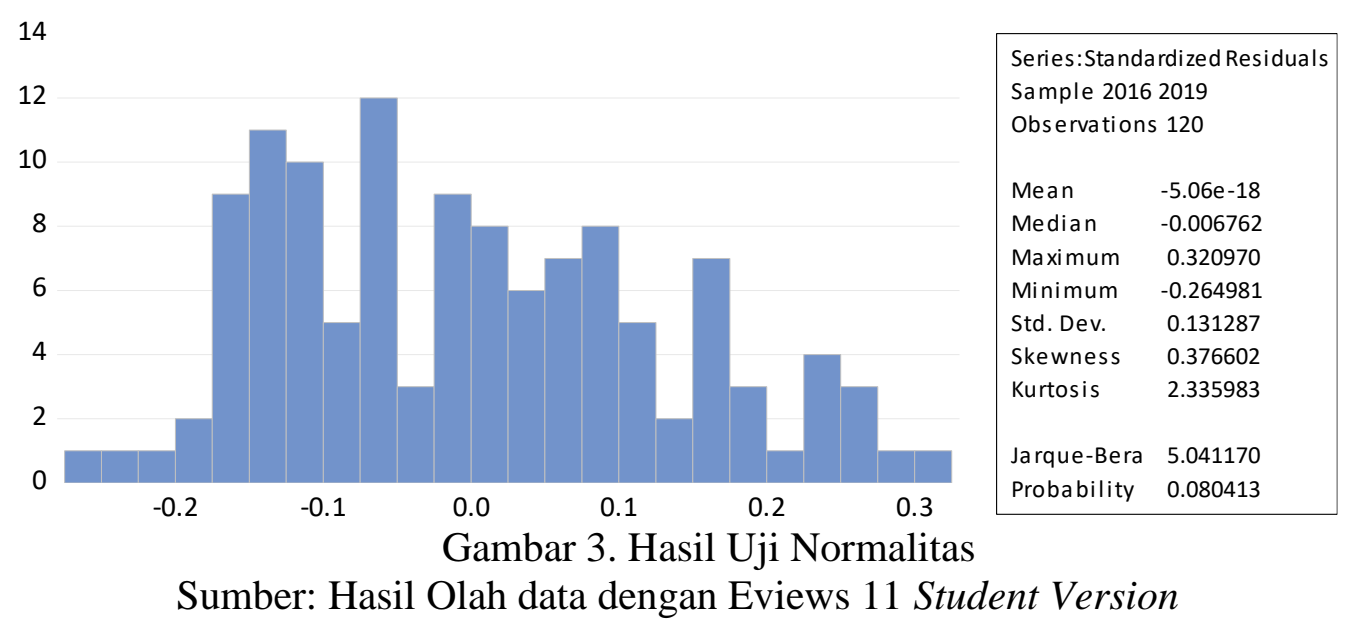

Nilai Jarque-Bera sebesar 5,041170 dan nilai probabilitas yang didapat adalah sebesar 0,080413, hal ini dapat disimpulkan jika model regresi dalam penelitian ini terdistribusi normal karena nilai probabilitasnya diatas tingkat $\alpha$, yaitu 0,05 .

Tabel 1. Hasil Uji Multikolinearitas

Sumber: Hasil Olah data dengan Eviews 11 Student Version

$\begin{array}{llll}\text { ROA } & \text { CR } & \text { COLL } & \text { IO }\end{array}$

\begin{tabular}{crrrr}
\hline \hline & & & & \\
ROA & 1,000000 & $-0,125734$ & $-0,111610$ & 0,300257 \\
CR & $-0,125734$ & 1,000000 & $-0,095692$ & $-0,213601$ \\
COLL & $-0,111610$ & $-0,095692$ & 1,000000 & 0,187160 \\
IO & 0,300257 & $-0,213601$ & 0,187160 & 1,000000
\end{tabular}

Uji Mutikolinearitas yang digunakan dalam penelitian ini adalah Variance Inflation Factors (VIF), dimana nilai dari VIF setiap variabel pada tabel 1 lebih kecil dari 0,8 maka tidak terjadi multikolinearitas dalam penelitian ini. 
Tabel 2. Hasil Analisis Regresi Berganda

Sumber: Hasil Olah Data dengan Eviews 11 Student Version

Dependent Variable: CS

Method: Panel EGLS (Cross-section random effects)

Date: $12 / 03 / 20$ Time: $22: 28$

Sample: 20162019

Periods included: 4

Cross-sections included: 30

Total panel (balanced) observations: 120

Swamy and Arora estimator of component variances

\begin{tabular}{ccrrr}
\hline \hline Variable & Coefficient & Std. Error & t-Statistic & Prob. \\
\hline \hline ROA & $-0,264771$ & 0,096907 & $-2,732230$ & 0,0073 \\
CR & 0,005815 & 0,003125 & 1,860624 & 0,0654 \\
COLL & 0,036750 & 0,063845 & 0,575615 & 0,5660 \\
IO & 0,035110 & 0,004418 & 7,946941 & 0,0000 \\
C & 0,113889 & 0,026888 & 4,235670 & 0,0000 \\
\hline \hline
\end{tabular}

Effects Specification

\begin{tabular}{lrr} 
& S.D. & Rho \\
\hline \hline Cross-section random & 0,119853 & 0,8827 \\
Idiosyncratic random & 0,043686 & 0,1173 \\
\hline \hline
\end{tabular}

\begin{tabular}{llll}
\hline \hline & Weighted Statistics & \\
\hline \hline Root MSE & 0,043382 & R-squared & 0,374228 \\
Mean dependent var & 0,029625 & Adjusted R-squared & 0,352462 \\
S.D. dependent var & 0,055071 & S.E. of regression & 0,044315 \\
Sum squared resid & 0,225841 & F-statistic & 17,19327 \\
Durbin-Watson stat & 1,493251 & Prob(F-statistic) & 0,000000 \\
\hline \hline & Unweighted Statistics & 0,165228 \\
\hline \hline R-squared & $-0,044382$ & Mean dependent var & 0,164417 \\
Sum squared resid & 2,051107 & Durbin-Watson stat & \multirow{2}{*}{} \\
\hline \hline
\end{tabular}

Bedasarkan hasil dari penelitian yang dilakukan diperoleh persamaan regresi sebagai berikut: $\mathrm{CS}=0,113889-0,264771 \mathrm{ROA}+0,005815 \mathrm{CR}+0,036750 \mathrm{COLL}+0,035110 \mathrm{IO}$

\section{Hasil Uji Parsial (Uji-t) \\ Uji-t variabel ROA}

Pada tabel 2 diatas, menunjukkan nilai probabilitas variabel ROA adalah sebesar 0,0073 kurang dari $\alpha 0,05$, yang berarti $\mathrm{H} 0$ ditolak dan Ha diterima maka disimpulkan ROA memiliki pengaruh yang signifikan terhadap struktur modal.

\section{Uji-t variabel CR}

Pada tabel 2 diatas, menunjukkan nilai probabilitas variabel CR adalah sebesar 0,0654 lebih dari 0,05, yang berarti H0 diterima dan Ha ditolak maka disimpulkan CR tidak memiliki pengaruh yang signifikan terhadap struktur modal. 


\section{Uji-t variabel COLL}

Pada Tabel 2 diatas, menunjukkan nilai probabilitas variabel COLL adalah sebesar 0,5560 lebih dari 0,05, yang berarti H0 diterima dan Ha ditolak maka disimpulkan COLL tidak memiliki pengaruh yang signifikan terhadap struktur modal.

\section{Uji-t variabel IO}

Pada tabel 2 diatas, menunjukkan nilai probabilitas variabel IO adalah sebesar 0,0000 kurang dari 0,05 , yang berarti $\mathrm{HO}$ ditolak dan Ha diterima maka disimpulkan IO memiliki pengaruh yang signifikan terhadap struktur modal.

Hasil Uji Simultan (Uji F). Pada tabel 2 diatas ditunjukkan nilai probabilitas F- statistic adalah sebesar 0,0000 kurang dari 0,05, yang berarti H0 ditolak dan Ha diterima maka dapat disimpulkan variabel independen (profitabilitas, likuiditas, collateral, dan investment opportunity) secara simultan memiliki pengaruh yang signifikan terhadap struktur modal secara simultan.

\section{Hasil Uji Koefisien Determinasi $\left(\mathbf{R}^{2}\right)$.}

Pada tabel 2 diatas ditunjukkan nilai dari $\mathrm{R}^{2}$ adalah sebesar 0,352462 atau 35,24\%, yang dapat disimpulkan bahwa sebanyak 35,24\% perubahan struktur modal dapat dijelaskan oleh ROA, CR, COLL dan IO sedangkan sisanya yaitu sebanyak $64,76 \%$ perubahan variabel dependen dipengaruhi oleh variabel lain yang tidak ada dalam penelitian ini.

\section{Diskusi}

Berdasarkan hasil pengujian yang dilakukan diketahui, Profitabilitas memiliki pengaruh yang negative dan signifikan terhadap struktur modal perusahaan hal ini dapat dijelaskan dengan pecking order theory yang menyatakan bahwa jika suatu perusahaan memiliki profitabilitas yang tinggi, perusahaan tersebut cenderung menggunakan pendanaan yang bersifat internal untuk memenuhi kebutuhan pembiayaannya, dan jika hasil profitabilitas sudah tidak lagi mencukupi untuk mendanai perusahaan, maka perusahaan baru akan menggunakan alternative hutang.

Likuiditas tidak memiliki pengaruh terhadap struktur modal perusahaan hal ini dikarenakan pengujian struktur modal dalam penelitian ini hanya memperhatikan faktor pengunaan hutang jangka panjang saja, sehingga likuiditas (hutang lancar/hutang jangka pendek) tidak mempengaruhi pengambilan keputusan struktur modal. Menurut Chandra et al., (2019) perusahaan dengan likuiditas yang besar tidak sepenuhnya menggunakan likuditas sebagai dana internal, sehingga likuiditas tidak akan mempengaruhi kebijakan struktur modal.

Collateral tidak memiliki pengaruh terhadap struktur modal perusahaan hal ini dikarenakan pengunaan jaminan dalam mendapatkan pendanaan biasa nya hanya diperlukan oleh perusahaan yang baru saja dirintis (start-up), yang dimana jaminan berupa aset berwujud dibutuhkan untuk menurunkan risiko debitur gagal bayar. Sedangkan dalam penelitian ini perusahaan yang diteliti merupakan perusahaan yang sudah cukup besar, yang dimana nilai aset tetap yang tinggi tidak dijadikan sebagai acuan untuk mendapatkan pinjaman, bagi para investor nilai aset yang bisa dijadikan sebagai jaminan memang akan menjadi bahan pertimbangan tetapi hal itu bukan lah faktor utama yang diperhatikan dalam memberikan pinjaman. 
Investment opportunity memiliki pengaruh yang positif dan signifikan terhadap struktur modal perusahaan hal ini dapat dijelaskan dengan pecking order theory yang menyatakan bahwa perusahaan yang memiliki kesempatan investasi (Investment Opportunity) yang tinggi akan cenderung membutuhkan dana yang besar, kebutuhan dana yang besar ini akan mendorong perusahaan untuk menggunakan pendanaan berupa hutang (eksternal) dikarenakan kebutuhan akan dana yang besar itu tidak dapat dipenuhi hanya dari sumber internal saja.

\section{KESIMPULAN DAN SARAN}

Berdasarkan hasil pengujian yang sudah dilakukan maka dapat ditarik kesimpulan bahwa variabel profitabilitas memiliki pengaruh yang negative dan signifikan terhadap struktur modal dan investment opportunity mempunyai pengaruh yang positif dan signifikan terhadap struktur modal, sedangkan likuiditas dan collateral tidak mempunyai pengaruh yang signfikaan terhadap struktur modal. Sedangkan secara simultan profitabilitas, likuiditas, collateral dan investment opportunity mempunyai pengaruh yang signifikan terhadap struktur modal.

\section{REFERENSI}

Alipour, M., Mohammadi, M. F., \& Derakhshan, H. (2015). Determinants of capital structure: an empirical study of firms in Iran. International Journal of Law and Management, 57(1), 5383.

Basri, M. F., Shoib, F. S., \& Kamaralzaman, S. (2019). Determinants of Capital Structure: Evidence From Malaysian Food and Beverage Firms. Research in World Economy, 10(5), 45-52.

Chandra, T., Junaedi, A. T., Wijaya, E., Suharti, S., Mimelientesa, I., \& Ng, M. (2019). The effect of capital structure on profitability and stock returns. Journal of Chinese Economic and Foreign Trade Studies, 12(2), 74-89.

Dhani, I. P., \& Utama, A. S. (2017). Pengaruh Pertumbuhan Perusahaan, Struktur Modal, dan Profitabilitas Terhadap Nilai Perusahaan. Jurnal Riset Akuntansi dan Bisnis Airlangga, 2(1), 135-148.

Keown, A. J., Martin, J. D., Petty, J. W., \& Scott, JR, D. F. (2005). Financial Management: Principles and Applications (10th ed.). Pearson.

Khémiri, W., \& Noubbigh, H. (2018). Determinants of capital structure: Evidence from SubSaharan African firms. The Quarterly Review of Economics, 70, 150-159.

Kyissima, K. H., Xue, G. Z., Kossele, T. P., \& Abeid, R. A. (2020). Analysis of capital structure stability of listed firms in China. China Finance Review International, 213-228.

Melodie, N., \& Ruslim, H. (2019). Pengaruh Profitabilitas, Struktur Aktiva, Dan Ukuran Perusahaan Terhadap Struktur Modal. Jurnal Manajerial dan Kewirausahaan, 1(2), 297 306.

Nurcahyani, N., \& Suardikha, I. (2017). Investment Opportunity Set (IOS) sebagai Pemoderasi Pengaruh Stuktur Modal dan Kebijakan Dividem pada Nilai Perusahaan. E-Jurnal Ekonomi Dan Bisnis Universitas Udayana, . Retrieved from https://ojs.unud.ac.id/index.php/EEB/article/view/25031

Ruslim, H. (2009). Jurnal Bisnis dan Akuntansi. Pengujian Struktur Modal (teori pecking order): Analisis Empiris terhadap saham di LQ-45,11(3), 209221. https://jurnaltsm.id/index.php/JBA/article/download/245/220

Saif-Alyousfi, A. Y., Mud-Rus, R., Taufil-Mohd, K. N., Taib, H. M., \& Shahar, H. K. (2020). Determinants of capital structure: evidence from Malaysian firms. Asia-Pacific Journal of Business Administration, 1757-4323.

Sekaran, U., \& Bougie, R. (2016). Research Method for Business: A Skil Building Approach (Seventh ed.). Chichester, West Sussex, United Kingdom: John Wiley \& Sons. Ltd. 
Suryana, A. (2016). Pengaruh Cost of Borrowing, Profitability dan Collateral Value of Assets Terhadap Stuktur Modal Pada Perusahaan Real Estate Di Indonesia. Majalah Ilmiah Bijak, XIII(1), 11-28.

Wardani, S. L., \& Ruslim, H. (2020). Pengaruh Dar, Ukuran Perusahaan, Dan Tax Avoidance Terhadap Cost Of Debt. Jurnal Manajerial dan Kewirausahaan, 2(2), 469-478.

Wijaya, E., \& Jessica. (2017). Analysis of Effect of Structure of Assets, Its Size, Profitability, Growth Opportunities, Tangibility, Business Risk and Capital Structure Liquidity Against Sector Companies in The Property \& Real Estate Listed in Indonesia Stock Exchange in 2011-2015. PROCURATIO, 5(4), 440-451. 